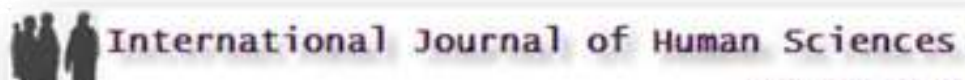 \\ ISSN:1303-5134
}

Volume: 11 Issue: 2 Year: 2014

\section{Analysing language classrooms through classroom interaction $^{1}$}

\author{
Müge Gündüz ${ }^{2}$
}

\begin{abstract}
This research study focuses on teacher-student and student-student interaction, which are considered very important aspects of classroom life. There has been a growth of interest in the analysis of teacher language and interaction in language classrooms and many (e.g. Ellis, 1994; Tsui, 2001) believe that classroom interaction is one of the major variables affecting SLA in formal settings. This study aims to give some insight into classroom interaction and how this interaction shapes L2 learning and teaching in Turkey and England. Systematic classroom observation along with the field notes taken to record observations is the main research method in this study used to describe and examine interaction patterns and to measure learner production in secondary classes in Turkey and England. The participants are foreign language teachers and non-native speaking students. Over a month, more than 50 lessons were observed in the secondary schools in both Turkey and England at two levels (13-14 and 14-15 year age group). In Turkey, English classes were observed whereas in England, the observation was conducted in German and French classes. English is taught as a foreign language in Turkey; German and French are also taught as a foreign language in England. The findings of this research study are expected to provide a better understanding of instructional practices and procedures in L2 classrooms. The results of this research study, however, should be seen as suggestive rather than conclusive since they are derived from a relatively small sample.
\end{abstract}

Keywords: Classroom Research; Systematic Observation; Classroom Interaction; L2 Teaching; Secondary Schools

\section{Introduction}

There has been a growth of the interest in the analysis of teacher language and interaction in language classrooms and many believe that classroom interaction is one of the major variables affecting SLA in formal settings. It has been recognized that successful outcomes in a classroom may depend on the type of language used by the teacher and the type of interactions occurring in

\footnotetext{
1 The data used in this paper is collected and analyzed as a part of a Doctoral Thesis.

${ }^{2}$ Instructor, Ph.D., METU, Faculty of Education, Department of Foreign Language Education, gmuge@metu.edu.tr
} 
Gündüz, M. (2014). Analysing language classrooms through through classroom interaction. International Journal of Human Sciences, 11(2), 1149-1166. doi: 10.14687/ijhs.v11i2.3044

the classroom. As van Lier (1988) puts it, 'if the keys to learning are exposure to input and meaningful interaction with other speakers, there is a need to investigate what input and interaction the classroom can provide' (p.94). 'Interaction' is an important process in language teaching. Learners are exposed to the target language and language samples become available to the learner for interlanguage construction through the classroom interaction process (Ellis, 1990). Tsui (1995) also defines 'classroom interaction' as the interaction between the teacher and students, and amongst the students in the classroom. This study focuses oral interaction in modern language classrooms and aims to investigate any qualitative and quantitative differences that exist between the ways that the teaching and learning of spoken language are handled pedagogically in Turkish and English secondary schools.

\section{The Purpose of the Study}

This study aims to provide research-based assistance to teachers and researchers on different orientations to language teaching and on the effectiveness of these differences for classroom language learning by analyzing oral interactions between teachers and students. Research such as this study might provide directly relevant information for teachers and educators and might be valuable to teachers who can identify with it. Understanding the ways in which classroom talk is "accomplished" (Mehan, 1979) is crucial to understanding of the role of interaction in SLA (Walsh 2006, p. 22). Therefore, it is particularly important for this study to establish the type of real classroom-based data which might provide directly relevant information for language teachers in the two different contexts. As Nunan (1987) puts it, it is necessary to have a realistic awareness about what is happening in the classroom in order to assist teachers in their professional development.

\section{Research Questions}

The research questions in this study are developed in the light of previous research and existing theories, which have been discussed so far, and they aim to explore the nature of classroom interaction in L2 classrooms in Turkish and English secondary schools. The research questions for this study are as follows:

1. Is there any difference in the way the modern language teachers organize the lessons in the two countries?

2. Is there any relationship between instructional differences (i.e. meaning-focused and grammarfocused instructions) and students' language production? 
Gündüz, M. (2014). Analysing language classrooms through through classroom interaction. International Journal of Human Sciences, 11(2), 1149-1166. doi: 10.14687/ijhs.v11i2.3044

\section{Method}

A systematic observation scheme - the Communicative Orientation of Language Teaching (the COLT) - Observation Scheme (Spada \& Frohlich, 1995) was adapted and used in this research study. Observation is commonly used in education as a tool to support understanding educational situations, evaluate the effectiveness of educational practices, and plan attempts for improvements (Malderez, 2003).

\section{Participants}

The data in this research was collected in two different contexts: Turkey and England. Over a month, more than 50 lessons were observed in the secondary schools in both Turkey and England at two levels (13-14 and 14-15 year age group). In Turkey, English classes were observed whereas in England, the observation was conducted in German and French classes. English is taught as a foreign language in Turkey; German and French are also taught as a foreign language in England. The participants in this study were modern language teachers and non-native speaking students in secondary schools in Turkey and in England. The observations analyzed in this article are summarized below:

Table 1: Summary of Classroom Observations

\begin{tabular}{llll}
\hline Turkey & 8 different classes & 5 teachers & 23 lessons \\
England & 13 different classes & 6 teachers & 31 lessons \\
Total & 21 classes & 11 teachers & 54 lessons \\
\hline
\end{tabular}

\section{Data Collection}

All the lessons were audio-recorded as a part of the COLT observation scheme. The researcher was just an observer taking no part in any activity in the classroom. The coding for all categories on Part A of the scheme was done in 'real time', in other words, this part of scheme was filled in while the observer was present in the classroom as the lesson unfolded. Part A describes classroom events at the level of activity. The basic unit of analysis in Part A is a change in activity. The activities were timed and the starting point for each activity was entered in the left-hand margin of the coding form. During the observation period the observer put check marks in all the relevant boxes under each of the major heading. While coding for Part A some additional notes were also taken in order to obtain a complete picture of the overall period of observation. 
During the observation process audio-recordings were made for later Part B transcription coding. Unlike the Part A coding which is done in 'real time', coding for Part B was done after the observation, using audio-recordings since this level of analysis is more detailed than Part A. During the recordings, the researcher was in the classroom and the participants were aware of the recordings. The occurrence of Part B features for the entire observation period was coded. The basic unit of analysis for coding and later for analysis for Part B was the teacher and student turn (i.e. any speech which is produced by a speaker until another person starts speaking). Within each student or teacher turn a check mark was put in the appropriate column whenever any relevant categories occurred. New check marks were entered only when there was a change in one of the categories; in other words, a new check mark was not placed when several uninterrupted instances of the same category occurred.

\section{The COLT Observation Scheme Part A: Classroom Events}

As in the case of the categories of Part A, the communicative features have been developed by a number of discussions in the current literature of first and second language acquisition, communicative language teaching, and communicative competence.

5 parameters are differentiated in Part A but only the following 3 parameters are analyzed for this piece of work:

Col.1 Time: The starting time of each activity and its episodes are entered.

Participant Organization: The category of participant organization in the COLT scheme refers to three basic patterns of organization for classroom interactions: 1.whole class 2. group-work 3. individual work

Content: 1. Language (Focus on Form): a. Form (Explicit focus on grammar, vocabulary, or pronunciation) b. Function c. Discourse d. Sociolinguistics. 2. Other Topics (Focus on Meaning): a. Narrow range of reference (Classroom, stereoype, personal/biography, other topics) b. Limited range of reference (Personal, routine/social, family, school topics, other topics) c. Broad range of reference (Abstract, personal/reference, imagination, world topic, other topics) .

\section{The COLT Observation Scheme Part B: Communicative Features}

The second part of observation scheme (Part B) analyses the communicative features of verbal exchanges between teachers and student and/or students and students as they occur within each episode or activity. The rationale for Part B derives from the fact that the development of 
Gündüz, M. (2014). Analysing language classrooms through through classroom interaction. International Journal of Human Sciences, 11(2), 1149-1166. doi: 10.14687/ijhs.v11i2.3044

communicative competence is a major concern in the current language teaching literature, and constitutes one of the basic issues in the Development of Bilingual Proficiency (Allen et al., 1983).

This section of the scheme is divided into the following 7 major parameters but only the following 4 parameters are analyzed for this piece of work:

I. Use of Target Language: 1. Use of First Language (L1) 2. Use of Target Language (L2)

II. Sustained Speech: 1. Ultra-minimal (utterances that consist of one word - coded for student speech only). 2. Minimal (utterances that consist of one clause or sentence; for the teacher, one-word utterances are coded as minimal) 3. Sustained (utterances that are longer than one sentence, or consist of at least two main clauses)

III. Discourse Initiation: This parameter refers to spontaneously initiated talk by students instead of just giving responses to questions imposed on them.

IV. Form Restriction: This parameter refers to the degrees of linguistic restriction imposed upon the student utterances. 1. Restricted (the production of one specific form is expected). 2. Unrestricted (there is no expectation of any particular linguistic form, as in free conversation, oral reports, or personal diary writing).

\section{Data Analysis}

For COLT A, the percentage of time spent on each of the categories under the major features (e.g. 'Participant Organization', Content', etc.) was calculated. By doing these calculations, it is hoped that within the category 'Participant Organization', for example, what percentage of classroom time the teacher worked with the whole class or did group-work will be illustrated. In order to provide these percentages, it is necessary to calculate the percentage of time spent on each particular category.

For COLT Part A, each activity and episode was timed and numbered during the observation period in order to determine the percentage time spent on the various categories both within individual activities/episodes as well as across the entire lesson.

If two or more categories were checked off under the same major heading, the primary focus should be indicated according to the time spent on a particular category. If two or more categories were considered to be equal focus, the same amount of time and emphasis spent on more than one category. The COLT scheme allows researcher to do double coding in Part A which indicates equal focus on two features. 
The Part B analysis focuses on the verbal output and the interactions of teachers and students and thus, it is more detailed than the Part A analysis. Each check mark in a particular column of Part B was counted and divided by the total numbers of check marks under that particular feature. This procedure was followed for all categories of part B for both teacher and student verbal interaction. It was hoped that the audio-recordings of the lessons would provide a detailed description of the verbal interactions between teacher-student and student-student in the language classrooms observed.

Reliability of this study is believed to have been strengthened by being consistent in analysis and in the interpretation of the COLT scheme across all coding since the same rater coded all observation schemes and audio-recordings. In addition, detailed classroom observation notes helped the researcher in coding high inference categories in real time. Since the COLT scheme had been used in many other studies before, the researcher chose to use the same categories, without bringing many modifications into the scheme in order to enhance the reliability of this particular study.

\section{Findings and Discussion}

Since this study includes a relatively small sample of language teaching it only aims to give some insight into classroom interaction and how this interaction shapes L2 learning and teaching in the two countries in which this research study was conducted. Therefore, the suggestions and the indications of the findings of this study will be tentative rather than conclusive. From a theoretical perspective it is hoped that the findings of this study will provide some implications for the questions raised and provide food for discussion on a number of pedagogic and theoretical issues. It is also expected that this study would provide possible future directions for further research.

In this section some parts of the combined data for the Year 9 and 10 classes will be presented in order to provide an overview of the features of classroom interaction in Year 9/10 classes in England and Turkey. The results of the observations conducted in Year 9 and Year 10 classes were combined and this section will summarize some important features of classroom interaction based on the findings of these observations. The mean percentage of observed time in each category in Part A and the mean percentage for each category in Part B, deriving from frequencies for the classes observed in England and Turkey will be presented below.

\section{Participant Organisation}

Participant organization is a major variable in classroom interaction, and it should be included in any observation scheme in classroom-based research. The category of participant organization in 
Gündüz, M. (2014). Analysing language classrooms through through classroom interaction. International Journal of Human Sciences, 11(2), 1149-1166. doi: 10.14687/ijhs.v11i2.3044

the COLT scheme refers to three basic patterns of organization for classroom interactions: 1 . whole-class work 2. group-work 3. individual work.

There was a very limited student-to-student/class organization; therefore, students had not many opportunities to participate in classroom interaction. There was little emphasis on pair/group work in language classrooms in both countries. Language classes observed in England spent markedly more time on pair/group work than their Turkish counterparts (12\% compared to only about $2 \%$ ) (see Figure 1). The findings of SLA research that group work helps the teacher to create a positive and relaxed atmosphere (Foster, 1998) and also encourages the teacher take a less direct and more facilitative role (Hawkes, 2012) appear not to have been applied into the classroom contexts observed in either country.

\section{Figure 1: Participant Organization as a Percentage of Observed Time}

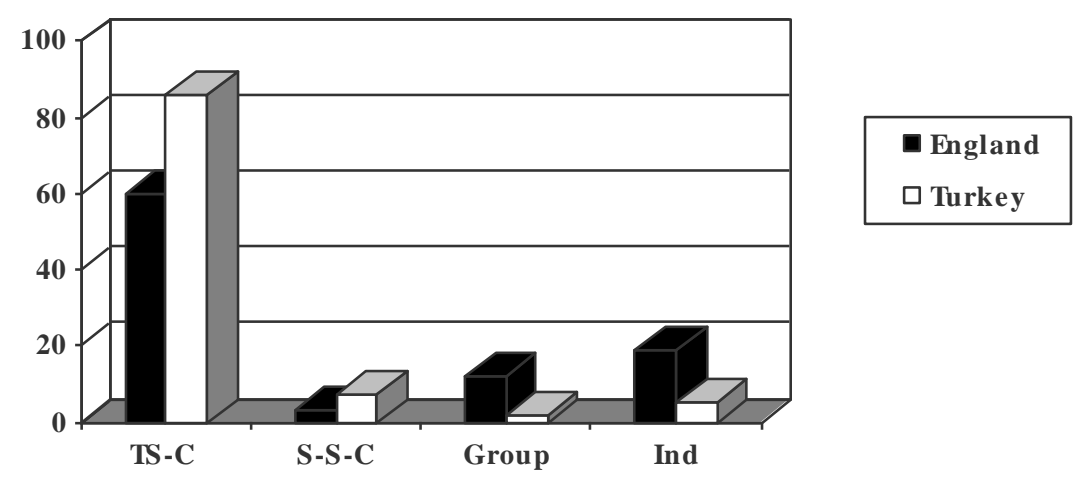

As Chappell (2014) points out, classroom researchers have been making considerable efforts over several decades to understand the talk that takes place between teachers and students. From a great deal of discourse and conversation analytic research on classroom interaction we know that the Initiation-Respond-Feedback (IRF) organization is the default interactional practice for all curricular areas including the contexts of second and foreign language classrooms (e.g., Poole 1992; Hall 1995, 1998, 2004; Hellermann 2003, 2005; Seedhouse 2004)" (cited in Hall 2010, p. 206). As Hall (2010) suggests a great deal about the kind of language knowledge learners are expected and if the IRF were the only practice, it would certainly constrain learners' development of using the target language outside the classroom.

The findings of this study provide a support to the claim developed by some previous researchers (Prabhu, 1987; Fazio \& Lyster, 1997) that the greatest percentage of time in L2 classrooms was spent in teacher-led whole class activities and IRF is the main pattern of interaction between the teacher and learner manner, as illustrated below: 
Gündüz, M. (2014). Analysing language classrooms through through classroom interaction. International Journal of Human Sciences, 11(2), 1149-1166. doi: 10.14687/ijhs.v11i2.3044

\section{Extract 1 (England)}

1. T: Yes, "countryside", that's right. Try to think of key words, huh? Don't worry too much if you don't understand all the words. Nobody expects you to understand all the words but key words, pick up key words, OK? C = 'C'est comfortable'.

2. Ss: Comfortable.

3. T: Yes, 'comfortable', 'it's comfortable'. D = 'On est libre', 'libre'.

4. Ss: 'Free'.

5. T: 'Free', well done.

\section{Extract 2 (Turkey)}

1. ...OK, look at the indirect question on the board. 'He asked where she was going.' Now let's look at both the direct question and indirect speech, so we can compare them. Have you noticed anything? In direct speech, it was "Where is she going?" In indirect speech it is "Where she was going". What is the difference between these two sentences?)

2. Ss: Yardımcı fill. (the auxiliary verb.)

3. T: Yer değiştiren ne? (What has changed here?)

4. S1: 'Is' 'was' oldu past haline geldi. (We have used the past form of the verb 'be'.)

5. T: Özne ile ne yer değiştirdi? (What has the subject swapped place with in the sentence?)

6. Ss: Yardımc1 fill. (the auxiliary verb)

Research (e.g. Chaudron, 1988; Gupta, 2004; Hulen, 1989; Nunan, 1991; Sakui, 2004) shows that teacher talk most of time in a classroom and controls the classroom interaction As Carless (2008) finds out in his study that secondary school language classrooms relied heavily on teacher input with teachers driving the lesson and doing most of the talking. This piece of study also indicates that language classes in both countries were mainly teacher-centered and teachers controlled the classroom discourse to a higher degree as indicated below:

\section{Figure 2: Total Teacher and Student Turns}

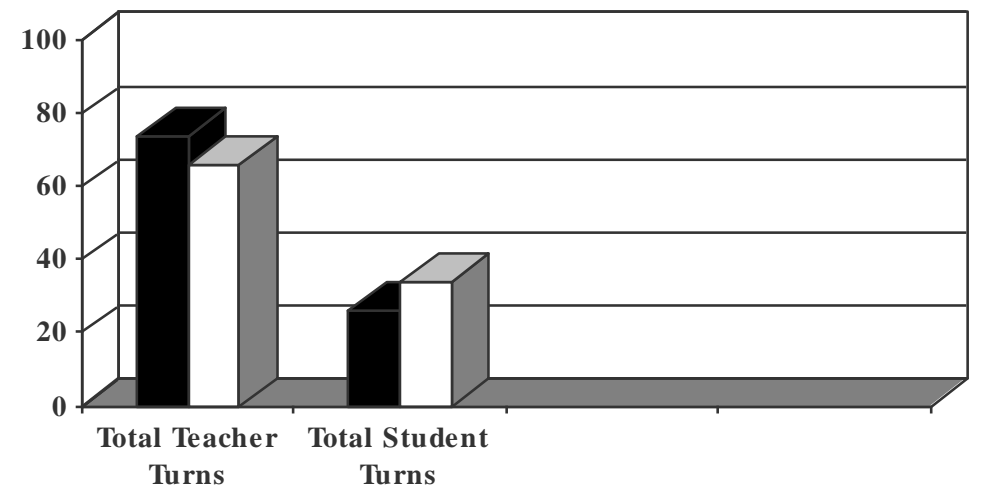


Gündüz, M. (2014). Analysing language classrooms through through classroom interaction. International Journal of Human Sciences, 11(2), 1149-1166. doi: 10.14687/ijhs.v11i2.3044

\section{Content (Focus on Form/Focus on Meaning)}

Many have taken the view that classrooms in which the focus on meaning-based instruction, group work and creative language-use opportunities are 'good' and teacher-centered classrooms with a focus on forms, correction and restricted language use are 'bad'. Today, the research findings on this issue are somewhat controversial. "The debate revolves around the degree to which teachers need to direct learners' attention to understanding grammar whilst retaining a focus on the need to communicate' (Sheen 2002, p. 303). Thus, on the one hand, there are those (e.g. De Keyser, 1998) who advocate separate and explicit attention to grammar and teaching of discrete points of grammar. There are other researchers (e.g. Doughty and Varela, 1998), on the other hand, who advocate minimal interruption to communication by limiting attention to grammar. These two different views have been encapsulated by Long's proposal $(1988,1991,2000)$ that grammar instruction can be presented in two ways: 'focus on form' and 'focus on formS' (Sheen, 2002). This approach assumes that 'comprehensible input is best experienced through classroom interaction, which is supported by attention to form provided incidentally when justified by communicative need' (cited in Sheen 2003, p. 225). Long (2000) emphasises the need for learners to attend to form consciously while they are communicating - what he calls 'focus on form'. The latter, on the other hand, is associated with the traditional teaching of linguistic points in separate lessons, and as such also includes the approach advocated by De Keyser (1998). As Batstone (2012) points out "teachers and researchers have long been concerned with the question of how best to develop both learners' knowledge of language form and their ability to put that knowledge into action in language use (p.465). Willis and Willis (2009) described "how findings in L2 acquisition research have suggested that it is this focus on meaning that allows a learner's grammatical system to progress" (cited in Hawkes 2012, p.327).

As with communicative features of interaction, the focus on forms and/or meaning in each class differed across schools and across countries. Classes in the schools observed in both countries focused on language form (grammar, vocabulary, etc., as the COLT scheme defines it) more than on the message being conveyed. These findings support the fact that ESL teachers still emphasize forms over meaning, accuracy over communication. (see Figure 3).

Figure 3: Focus on Language Form/Message and both on Form-Message
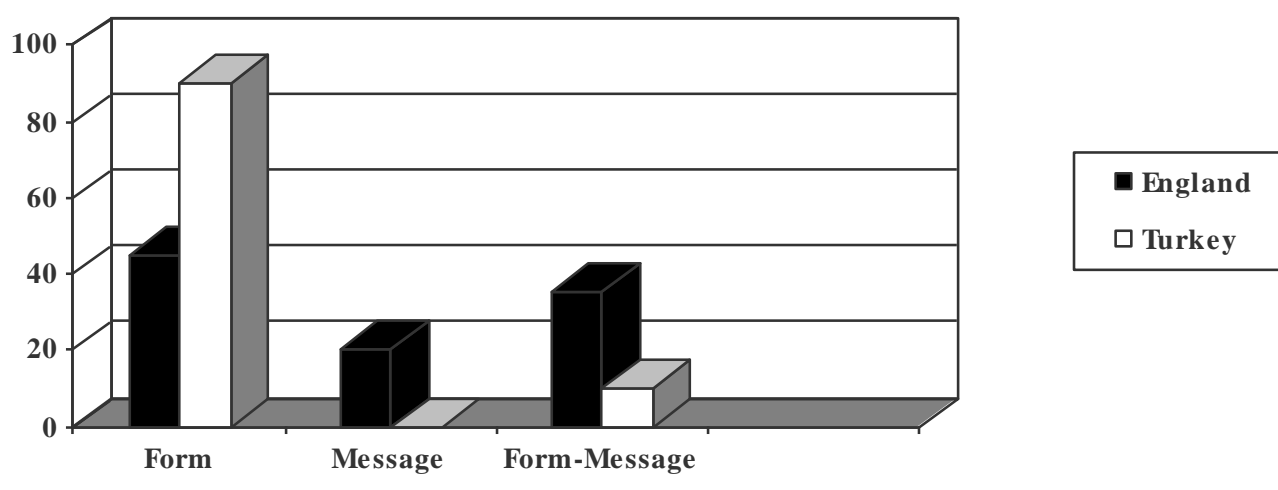
As the data suggests classes in the schools observed in both countries focused on language form (grammar, vocabulary, etc.) as illustrated below:

\section{Extract 3 (England)}

1. T: OK, let's look at the new words. OK. Here we go. OK on y va. .... C = un village de vacance, qu'est ce que c'est "un village de vacance?"...qu'est-ce que c'est? Levez la main, qu'est - ce que c'est un village de vacance? Un village, huh? Un village? - (What does "un village de vacance" mean? Hands up. What does "un village de vacance" mean? Un village, huh?).

2 Ss: village.

3 T: village. Oui, levez la main. (Yes, put your hands up). "De vacance"?

4 Ss: Holiday.

5 T: Holiday, that's right. So, "un village de vacance = a holiday village". "Un gite"? I am not sure you know that word. "Un gite", qu'est ce que c'est "un gite"? Non, personne me sait? (What does "un gite" mean? Anybody knows this word? "Un gite".

\section{Extract 4 (Turkey)}

1 T: Gecen ders 'Indirect' cümleyi 'Direct' cümleye çeviriyorduk. Evet onla ilgili örnekleri çoğaltalım bu ders. Evet, kim yapacak? Evet, 'John said he would fly to

England in March' (Last lesson we learnt how to turn Indirect speech into Direct.

Let's do more exercises on this. The first exercise in the text-book: 'John said he would fly to England in March'. Who would like to do it?

7. S1: Öğretmenim ben yapabilir miyim? (Can I do it Miss?)

8. T: Tahtaya gel (Ok, come on here and write it on the board).

9. [The student starts writing the exercise on the board]

10. T: Önce yazdığın Indirect cümleyi oku sonra Direct cümleyi oku (OK, now first read the Indirect sentence and then read the Direct one).

11. S1: John said he would fly England...England in March.

There was very little time spent explicitly focusing on the discourse and sociolinguistics features of the linguistic system in all the classes observed, which indicates that teachers in this study did not put much effort into directing students' attention towards these language features, as illustrated in Figure 4. 
Gündüz, M. (2014). Analysing language classrooms through through classroom interaction. International Journal of Human Sciences, 11(2), 1149-1166. doi: 10.14687/ijhs.v11i2.3044

Figure 4: Language Features

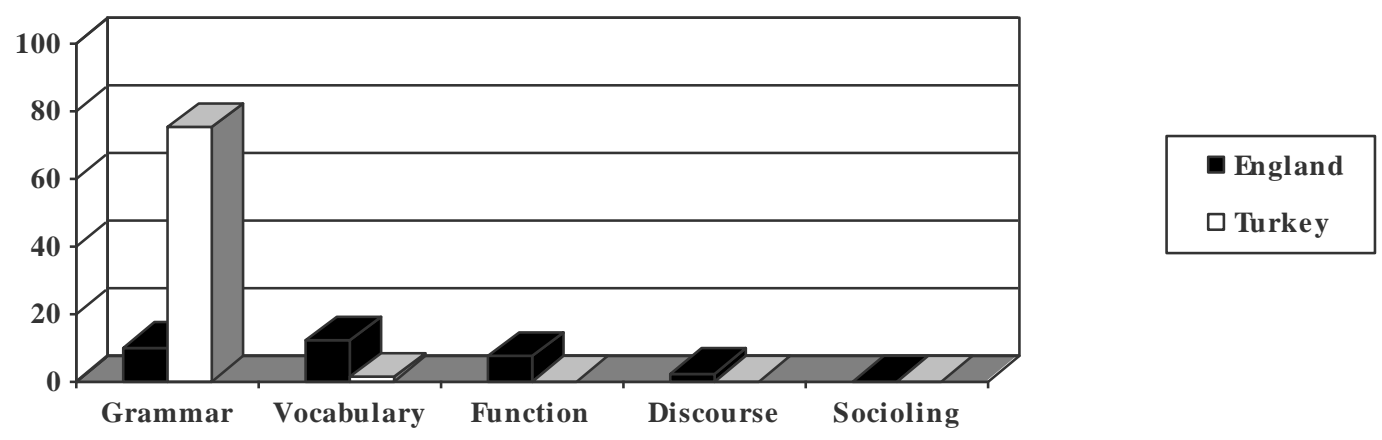

\section{Use of Target Language}

As Moore (2013) suggests, both cognitive second language acquisition (SLA) theory (e.g., Duff \& Polio, 1990; Polio \& Duff, 1994) and Communicative Language Teaching (CLT) methodologies have been cited as providing empirical support for the "English only" classroom, where use of the L1 is seen as a "problem" to be avoided (Auerbach, 1993; Cook, 2001; Edstrom, 2006; Turnbull \& Dailey-O'Cain, 2009) (cited in Moore, 2013, p. 239). However, Cook (2001) argues that there is no evidence that code-switching is inappropriate in a language classroom and he claims that SLA research provides no reason why it is not rational to use L1 in the classroom. Carless (2008) in his study investigates that most of the teachers considers L2 use to be inevitable in order to maintain students' attention, interest or involvement and contributions in the classroom practices. Scott \& de la Fuente (2008) also suggest that during form-focused tasks and activities, it may be more appropriate to encourage student interaction in the L1, at least initially, unless one aim of the task is to develop metalinguistic competence (cited in Moore 2013, p.251). However, Tomita \& Spada (2013) argue that in their study the results do not support the prediction that there would be more L2 communication during the form-focused activities than during the meaning-focused activities. 'Nonetheless, these findings are consistent with those of other empirical studies concerning the limited use of the L2 in classroom settings' (Canagarajah, 2001; Duff, 2004; Goldstein, 2003; Hall \& Verplaetse, 2000; Heller, 2006; Nakane, 2007; Pon et al., 2003; Storch \& Hill, 2008) (cited in Tomita and Spada, 2013, p.603). Some researchers (such as Zilm 1989, etc.) also discovered that when the teachers increased the use of the target language in class, the students' use of the target language rose proportionally.

The use of the first language (L1) by teachers and/or learners in the second or foreign language (L2) classroom remains a controversial issue. Teachers in the schools observed in England and Turkey used L1 to a great extent (55\% of teachers' utterances in England and 49\% of teachers' utterances in Turkey were in the mother tongue). Students, on the other hand, used the target 
Gündüz, M. (2014). Analysing language classrooms through through classroom interaction. International Journal of Human Sciences, 11(2), 1149-1166. doi: 10.14687/ijhs.v11i2.3044

language in the classroom more than their teachers (55\% of student utterances in England and 83\% of student utterances in Turkey were in the target language) (see Figure 5).

Figure 5: Teachers/Students' Use of Target Language in Total Turns

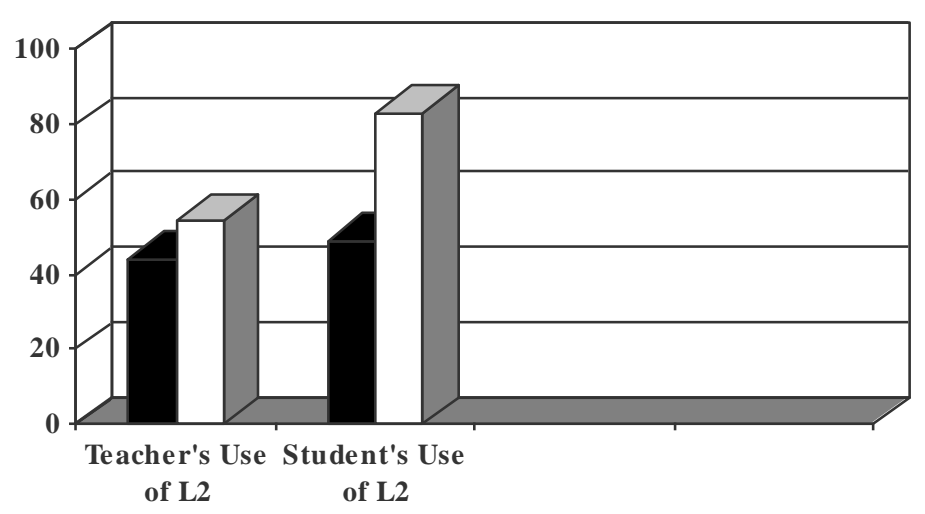

England

$\square$ Turkey

Language teachers in schools observed in both countries used L1 to a great extent in their speech turns observed. Students, on the other hand, used the target language more than their teachers did. Therefore, the findings of this study seem to provide some evidence regarding how the teachers' use of the target language affected the students' use of the target language, as illustrated below:

\section{Extract 5 (England)}

1. T: Excellent, yes, a youth hostel, huh? "Une chambre d'hote", qu'est ce que c'est "une chambre d'hote"?

2. Ss: Room.

3. T: Room, well done. In a room, room, what sort of room?

4. S1: Hot.

5. T: Hot, hot is an English word, the word we have here is "hote", h-o-t-e. It is a "guest", a room for guests, ... also could be a room in somebody's house.

\section{Extract 6 (Turkey)}

1. T: Which sport do you like? [the teacher nominates a student who puts her/his hand up]

2. S1: I like swimming.

3. T: Sorry?

4. S1: I like swimming.

5. T: Which sport does Burak like? [the teacher nominates a volunteer student]

6. S2: He likes swimming. 
Gündüz, M. (2014). Analysing language classrooms through through classroom interaction. International Journal of Human Sciences, 11(2), 1149-1166. doi: 10.14687/ijhs.v11i2.3044

However, this result might be explained that students were primarily engaged in teacher-controlled activities. Therefore, it might be the nature of the activity which explicitly focuses on grammar and vocabulary, as illustrated in Extract 3 and 4, and not the teachers' language use that influenced students' use of the target language.

Although students observed in this piece of research study used the target language in the classroom more than their teachers did, they generally produced restricted utterances as illustrated in Figure 6.

\section{Figure 6: Students' Sustained/Unrestricted Utterances and Student Initiation in Total Turns}

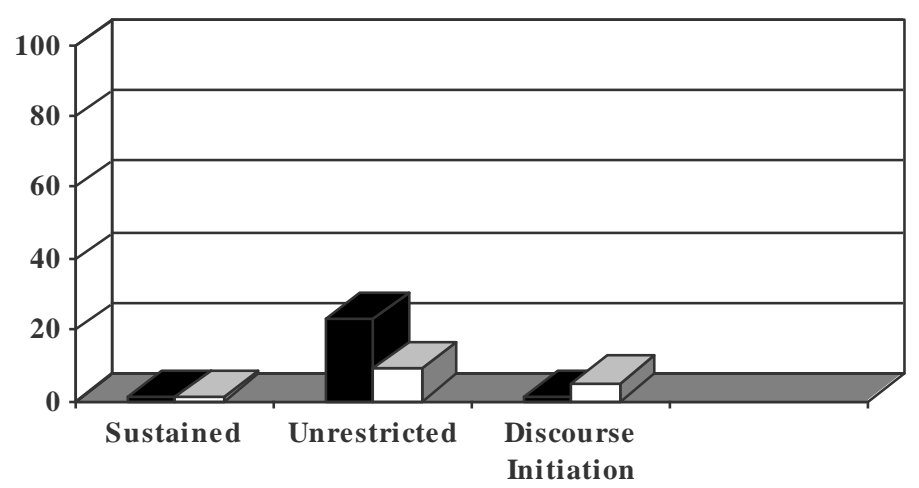

- England

$\square$ Turkey

Student talk is another important variable in classroom interaction. As Ellis (1994) indicates, students in a classroom context are often restricted to a responding role, therefore, their opportunities for participating productively in the L2 classroom are constrained. Harley et al. (1990) also reported that because student talk in teacher-fronted activities are restricted, and learners also have a limited number of opportunities they have to produce language which goes beyond simply getting their messages across. Therefore, the findings of this study provided some evidence regarding students' restricted responding role in classroom interaction. Swain and Carroll (1987) also predicted that providing more opportunities for student-initiated talk would increase the amount of sustained talk. Student initiation remained quite limited in the language classrooms observed in both countries. Although student initiation reached the highest percentage during the observations conducted in the schools observed in Turkey the amount of sustained student talk remained very limited in the schools observed in Turkey.

Although students in English classes produced more unrestricted utterances, they did not appear to use the target language to a greater extent or produce more sustained utterances than their Turkish counterparts observed in Turkish classes. Therefore, this study failed to provide clear evidence about the effect of using L2 in language classes on student language production. There was no 
Gündüz, M. (2014). Analysing language classrooms through through classroom interaction. International Journal of Human Sciences, 11(2), 1149-1166. doi: 10.14687/ijhs.v11i2.3044

direct correlation between the students' use of L2 and student language production in the classes observed.

\section{Conclusion}

As Holliday (1999) points out, there are secondary school classrooms all over the world with very similar seating arrangements and teacher-student behavior, despite national cultural differences. Indeed, this study provides some evidence that language teaching and classroom interaction have some similar features as well as different features in the two different countries observed. Language teaching and classroom interaction in secondary schools observed in England and Turkey appear to have some differences, but they also have some similarities, despite classroom culture differences in the two countries. Classes in the schools observed in both countries focused on language features more than on the message being conveyed. Similarly, this study provided evidence that classroom organization shows a tendency to teacher-centered classes. The main classroom organization was teacher-student/class in both countries. The findings of this study provide support to the claim that the greatest percentage of time in L2 classrooms was spent on teacher-led whole class activities. There was little emphasis on pair/group-work activities in all the schools observed in both countries. The findings of SLA research that group-work facilitates language acquisition and helps the teacher to create a positive and relaxed atmosphere appears not to have been applied in the classroom contexts observed in both countries.

Since most of the classroom interaction was tightly controlled by the teachers students' reliance on their interlanguage was minimal in the schools observed in both countries. Teachers in language classrooms used L1 to a great extent in their speech turns observed. As Hamilton (2004) suggests whether teacher's primary goal in a particular context is to provide opportunities for free-flowing conversation or to focus on language structure affects student talk and the fluency. Although much research demonstrated that whole-class interaction can negatively affect learner participation, Toth (2011) suggests that 'success is possible when the teacher's discursive power to set goals and manage turn-taking is wielded with care' (p.21). In this study although teachers mainly used whole class tasks, students used the target language more than their teachers did. However, students mostly produced minimal and restricted utterances because of the nature of the activity used in the classrooms. Similarly, this study failed to provide clear evidence about the effect of meaningfocused classes on student language production. There was no direct correlation between the communicative orientation of language classes and student language production in the classes observed. 
Gündüz, M. (2014). Analysing language classrooms through through classroom interaction. International Journal of Human Sciences, 11(2), 1149-1166. doi: 10.14687/ijhs.v11i2.3044

The results also showed that teachers talk most of the time and control the classroom interaction as many researchers suggested. That is to say, students in the classrooms observed responded to teachers' questions in most of their speech turns and produced restricted utterances. Thus, the findings of this study give support to the claim that students in a classroom context are often restricted to a responding role, therefore, their opportunities for participating productively in the L2 classroom are constrained. This should also be taken into consideration from the perspective of the qualities of an effective foreign language teacher as stated in the literature which suggests that teacher are expected to maintain positive teacher-student interaction by creating a positive classroom atmosphere (Arikan, Taşer \& Saraç-Süzer 2008; Arikan, 2010; Çelik, Arikan \& Caner, 2013).

It was concluded that the COLT observation scheme was able to differentiate between the classes observed in this study, both in terms of individual categories of interaction which capture the features intended to show the nature of communicative interaction in language classrooms and in terms of the final ranking procedure which gives sufficiently differentiated scores regarding communicative orientation of classrooms. Although the COLT observation scheme was able to differentiate well in terms of the nature of communicative interaction it did not provide any detailed information on how students negotiate for meaning or if they produce meaningful and grammatically correct sentences which would help the researcher to compare learners' achievement in each class. As Allen and Caroll (1988) indicate, because the COLT observation scheme was developed to provide a broad picture of the types of activity which characterize L2 classrooms, it does not enable researchers, for example, to pay sufficiently close attention to the exchange structure of discourse.

Because of the various limitations to the study specified above, the results in this research should be treated tentatively. More research is needed to validate the findings presented in this study. This study failed to provide a direct correlation between the percentage of student initiation and the length of student utterances. Although the length of student utterances varied across schools, student initiation remained quite limited in the language classrooms observed in both countries.

Finally, it is hoped that language teachers can find implications from the findings of this study for their classroom teaching. This study is also expected to provide a trigger for many more classroombased studies into foreign language teaching and learning in schools, particularly in Turkey. As Hellermann (2008) suggests that his own research on classroom interaction has informed his own teaching practice. Findings from that research can also be used to raise awareness in other practitioners of the reflexive nature of talk, and action in their own classrooms while policy makers 
Gündüz, M. (2014). Analysing language classrooms through through classroom interaction. International Journal of Human Sciences, 11(2), 1149-1166. doi: 10.14687/ijhs.v11i2.3044

are advised to work on teacher-student interaction as much as possible (Amir, 2013).

Microanalytical studies of the sequences of turns at talk in classroom will continue to offer insight that offers empirical evidence to support theoretical studies of power and student-teacher agency in the classroom.

\section{References}

Allen, P., Swain, M., Harley, B. \& Cummins, J. (1990). Aspects of classroom treatment: Toward a more comprehensive view of second language education. In B. Harley, P Allen, J. Cummins, \& M. Swain (Eds.), The Development of Second Language Proficiency (pp. 57-81). Cambridge: Cambridge University Press.

Amir, A. (2013). Self-policing in the English as a foreign language classroom. Novitas-ROYAL (Research on Youth and Language), 7(2), 84-105.

Arikan, A. (2010). Effective English language teacher from the perspectives of prospective and inservice teachers in Turkey. Electronic Journal of Social Sciences, 31, 209-223.

Arikan, A., Taşer, D., \& Saraç-Süzer, H. S. (2008). The effective English language teacher

from the perspectives of Turkish preparatory school students. Egitim ve Bilim [Education and Science], $33(150), 42-51$.

Batstone, R. (2012). Language form, task-based language teaching, and the classroom context. ELT Journal, 66(4), 459-467.

Carless, D. (2008). Student use of the mother tongue in the task-based classroom. ELT Journal, 62(4), 331-338.

Chapell, P. (2014). Engaging learners: conversation- or dialogic-driven pedagogy? ELT

Journal, 68(1), 1-11.

Chaudron, C. (1988). Second language classrooms. Cambridge: Cambridge University Press.

Cook, V. (2001). Second language learning and language teaching. London: Arnold.

Çelik, S., Arikan, A., \& Caner, M. (2013). In the eyes of Turkish EFL learners: What makes an effective foreign language teacher?. Porta Linguarum, 20, 287-297.

De Keyser, R. (1998). Beyond focus on form: Cognitive perspectives on learning and practising second language grammar. In C. Doughty \& J. Williams (Eds.), Focus on form in second language acquisition (pp.42-63). Cambridge: Cambridge University Press.

Doughty, C. \& Pica, T. (1986). Information-gap tasks: Do they facilitate second language acquisition? TESOL Quarterly, 20, 305-25.

Eggins, S. \& Slade, D. (1997). Analysing Casual Conversations, London, Cassell.

Ellis, R. (1990), Instructed Second Language Acquisition, Oxford, Blackwell.

Fazio, L. \& Lyster, R. (1997). COLT comparisons of second language learning environments in minority language and immersion classrooms, (manuscript submitted for publication).

Foster, P. (1998). A classroom perspective on the negotiation of meaning. Applied Linguistics, 19, 123.

Gupta, D. (2004). CLT in India: Context and methodology come together. ELT Journal, 58, 266269.

Hall, J.K. (2010) Interaction as method and result of language learning, Language Teaching, 43(2), 202-215. 
Gündüz, M. (2014). Analysing language classrooms through through classroom interaction. International Journal of Human Sciences, 11(2), 1149-1166. doi: 10.14687/ijhs.v11i2.3044

Hamilton, H. (2004). Repair of teenagers' spoken German in summer immersion programs. In D. Boxer \& A.D. Cohen (Eds.), Studying speaking to inform second language learning (pp. 88-114). Clevedon, Avon: Multilingual Matters.

Harley, B., Allen, P., Cummins, J., \& Swain, M. (1990). The development of second language proficiency. Cambridge: Cambridge University Press.

Hawkes, L.M. (2012). Using task repetition to direct learner attention and focus on form. ELT Journal, 66 (3), 327-335.

Hellermann, J. (2008). The co-construction of learning: Response sequences in a science class asthma project. In K. Cole \& J. Zuengler (Eds.), The research process in classroom discourse analysis: Current perspectives (pp. 49-72). London: Routledge.Holliday, M.A. (1999), 'Small Cultures', Applied Linguistics, vol.29, no.2, pp.237-64.

Hullen, W. (1989), 'Investigations into Classroom Discourse', in H. Dechert, (ed.) (1989), Current Trends in European Second Language Acquisition Research, Clevedon, Avon, Multilingual Matters.

Long, M. (1988). Focus on form: A design feature in language teaching methodology. Bellagio, Italy: Presentation given at the National Foreign Language Center, European Cultural Foundation Conference on Empirical Research on Second Language Learning in Institutional Settings.

Long, M. (1991). Focus on form: A design feature in language teaching methodology. In K. de Bot, D. Coste, R. Ginsberg, \& C. Kramsch (Eds.), Foreign language research in cross-cultural perspective (pp. 39-52). Amsterdam: John Benjamins.

Long, M. (2000). Focus on form in task-based language teaching. In R.D. Lambert \& E. Malderez, A. (2003). Observation. ELT Journal, 57, 179-181.

Mehan, H. (1979). Learning lessons: Social organization in the classroom. Cambridge, MA: Havard University Press.

Moore, P. (2013). An emergent perspective on the use of the first language in the EFL classroom. The Modern Language Journal 97(1): 239-253.Nunan, D. (1991). Methods in second language classroom oriented research. Studies in second language acquisition, 13, 249-274.

Prabhu, N.S. (1987), Second Language Pedagogy, Oxford, Oxford University Press.

Sakui, K. (2004). Wearing two pairs of shoes: Language teaching in Japan. ELT Journal, 58, 155-163.

Sheen, R. (2002). 'Focus on form' and 'Focus on Forms'. ELT Journal, 56, 303-305.

Sheen, R. (2003). Focus on form - A myth in the making? ELT Journal, 57, 225-233.

Spada, N. \& Frohlich, M. (1995). COLT Coding Conventions and Applications. Macquarie University: National Centre for English Language Teaching and Research (NCELTR).

Swain, M. \& Carroll, S. (1987). The immersion observation study. In B. Harley, P. Allen, J. Cummins, \& M. Swain (1987). The development of bilingual proficiency (final report, vol.1: Classroom treatment). Toronto: Modern Language Centre, Ontario Institute for Studies in Education.

Tomita and Spada (2013). Form-focused instruction and learner investment in L2 communication. The Modern language Journal 97(3), 591-610.

Toth, P. D. (2011). Social and cognitive factors in making teacher-led classroom discourse relevant for L2 grammatical development. The Modern Language Journal 95(1), 1-25.

Zilm, M. (1989). Investigating the role of code switching in oral language in the classroom. Adelaide: Languages and Multicultural Centre. 
Gündüz, M. (2014). Analysing language classrooms through through classroom interaction. International Journal of Human Sciences, 11(2), 1149-1166. doi: 10.14687/ijhs.v11i2.3044

\title{
Appendix
}

\section{Transcription Conventions}

In this study, the transcriptions were done according to the information given below:
a) Full-stop : It indicates certainty or completion. The absence of any turn-final punctuation indicates speaker incompletion, either through interruption or trailing off.
b) Comma, : These signal speaker parcelling of non-final talk. Thus, commas are used to make long utterances readable, and usually correspond to silent beats in the rhythm (but not breaks or pauses, which are marked with...).
c) Question mark ? : : These are used to indicate questions or to mark uncertainty.
d) Exclamation mark ! : This mark is used for the expression of 'surprise'.

e) Quotation mark “ ” : Speaker directly quotes another's speech.
f) ' '
: New vocabulary.

g) Empty parenthesis ( ) : Untranscribable segment of talk.

h) (Italics within : Uncertain transcription; transcriber's guess. parenthesis)

i) (Words within :In this study it is used for the translations parenthesis from German, French and Turkish.

j) [Word in square bracket]

: Information about relevant non-verbal behaviour. Such information is only included where it is judged important in making sense of the interaction.

\section{k) Three dots $\ldots \quad$ : Short hesitations between utterances are} defined as brief pauses within turns.

1) Square brackets [ ] : Significant pauses or lulls in the conversation between turns.

m) Double equals $==\quad$ : Overlap phenomena
n) Dash - then talk $\quad$ : A false start occur when a speaker "rethinks" aloud and rephrases what they were saying before completing the first version.

o) Fillers

$$
\begin{aligned}
& \text { : The most commonly used fillers are } \\
& \text { represented as follows: } \\
& \text { i) umm: doubt } \\
& \text { ii) ah: staller } \\
& \text { iii) mmm : agreement, confirmation } \\
& \text { iv) oh: other reaction } \\
& \text { v) huh: asking for confirmation } \\
& \text { vi) ssstt: discipline }
\end{aligned}
$$

p) Participants

\author{
i) $\mathrm{T}:$ Teacher \\ ii) $\mathrm{S} 1$ : Identified student, using numbers \\ iii) Ss : Unidentified a group of students \\ speaking in chorus.
}

(Adapted from Eggins and Slade 1997; Musumeci 1996). 